\title{
Ioncsere-folyamatok az agyagásványok „nanolaboratóriumában”
}

\author{
M. NAGY ${ }^{1}$ Noémi \\ Debreceni Egyetem, Fizikai Kémiai Tanszék, Imre Lajos Izotóplaboratórium, Egyetem tér 1. 4032 Debrecen, Magyarország
}

\section{Bevezetés}

Az ioncsere-folyamatokat a XIX. század közepén a talajokkal kapcsolatos kutatások során fedezték fel ${ }^{1-4}$. A talajok ioncserélö képességének jelentős részét a rétegrácsos szerkezetü aluminoszilikátok, az agyagásványok adják.

Az agyagásványok a magmás kőzetek földpátjainak bomlása során alakulnak ki, mállási helyükön vagy víz által elszállítva, legtöbbször tengeri üledék formájában keletkeznek, de a finom szemcsék leülepedhetnek mocsarakban, tavakban és folyómedrekben is. Alapvető szerkezeti egységeik a $\mathrm{SiO}_{4}$-tetraéderek és az AlOOH-oktaéderek, melyek összekapcsolódásának sokfélesége biztosítja az agyagásványok változatos szerkezetét, igen nagy számát. Jelentős kationcsere-kapacitása azoknak az agyagásványoknak van, ahol az oktaéderben a háromértékü kationt kétértékü kation (pl. magnéziumion, vas(II)-ion), ill. a tetraéderben a négyértékü szilíciumot háromértékü kation (pl. alumíniumion) helyettesíti. Ezen izomorf helyettesítések az aluminoszilikát vázat negatív töltésüvé teszik, amelyeket kicserélhető kationok semlegesítenek. Jelentős kationcsere-kapacitásuk van a szmektit típusú rétegszilikátoknak, melyek fontos képviselője a montmorillonit (1. ábra). A montmorillonitot fó komponensként tartalmazó agyagkőzetek a bentonitok, melyeknek igen sok mezőgazdasági, ipari, környezetvédelmi alkalmazása van ${ }^{5}$. A dolgozat bemutatja, hogy a kationcsere hogyan hat a montmorillonit szerkezetére, tulajdonságaira, milyen felhasználási lehetőségeket nyújt, illetve milyen problémákat vet fel.

Az agyagkőzetek ioncsere-folyamatainak vizsgálata során a következőkre kell figyelemmel lenni:

- Természetes anyagról lévén szó, az összetétel, a rétegtöltés és a kationcsere-kapacitás a lelőhellyel változik

- A kationcsere a rétegek közötti nagy elektrosztatikus térerejü zárt térben történik

- A rétegek közötti térben a hidratált kationok koncentrációja nagy

- Vízfelvétel hatására a rétegek duzzadnak; ennek mértéke függ a rétegek közötti kation milyenségétöl

- a montmorillonit képlékeny és önterülö

- nagy fajlagos felülete miatt a kationcsere mellett adszorpció is lehetséges

- a rétegek közötti térben, a „nanolaboratóriumban” levő kationok, illetve egyéb adszorbeált anyagok kémiai reakciókban vehetnek részt, illetve azokat katalizálhatják

- a montmorillonit savas karakterü.
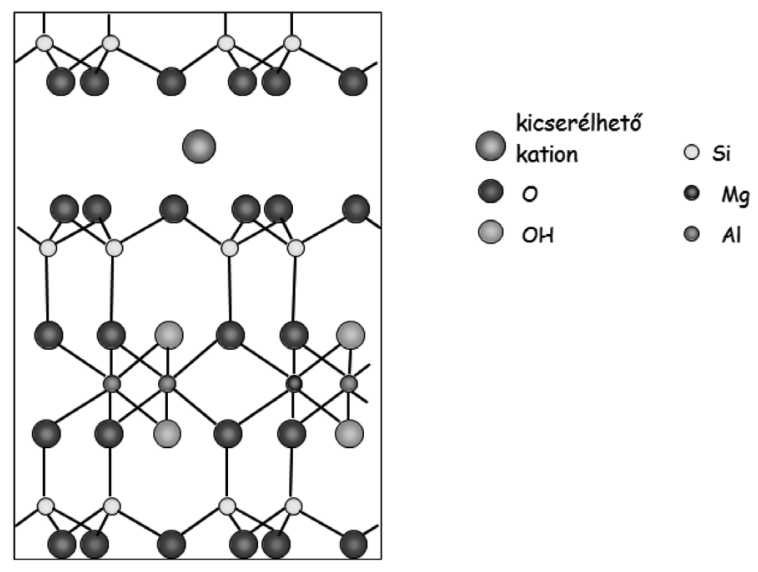

1. Ábra. A montmorillonit idealizált szerkezete

\section{Az ioncsere kezelésének termodinamikai szemlélete}

$\mathrm{Az}$ oldat/szilárd határfelületi ioncsere-folyamatok korrekt termodinamikai leírása azért nehéz, mert a folyamat heterogén rendszerben játszódik le és a jellemző mennyiségek függhetnek az ionok felületi móltörtjétől. Ezt a tényt a különböző modellek eltérő módon kezelik, pl. felületi aktivitási koefficiens, felületi elektromos munka, vagy felületi energia-eloszlási függvény alkalmazásával. Azonban ezek egyike sem mérhető meg közvetlen kísérleti úton, csak az ionok megoszlási adataiból becsülhető. A kísérleti adatokra legjobban illeszkedő modell azonban nem feltétlenül ad termodinamikailag értelmezhető eredményeket. Ugyanakkor sok közlemény nem foglalkozik a szorpciós mechanizmusok pontos értelmezésével. Ennek gyakori példája, amikor megállapítják, hogy ioncsere történik, majd erre adszorpciós modelleket alkalmaznak, így jelentés nélküli izoterma-adatokat és termodinamikai jellemzőket használnak a határfelületi jelenségek prognosztizálására.

Az adszorpciós modellek alkalmazása az ioncserére azért helytelen, mert az adszorpció a felület üres helyein történik, hajtóereje a felületi energia csökkentése. $\mathrm{Pl} . \mathrm{z}_{\mathrm{A}}+$ pozitív töltésü $\mathrm{Me}_{\mathrm{A}}$ kation adszorpciója:

$$
\mathrm{S}+\mathrm{Me}_{\mathrm{A}}^{\mathrm{zA}+} \rightleftharpoons \mathrm{Me}_{\mathrm{A}}^{\mathrm{zA}+}-\mathrm{S}
$$

ahol S a felületi kötőhelyeket jelenti. Ha két vagy több anyag kötődik meg ilyen módon, kompetitív adszorpcióról beszélünk. Ilyen esetben a $\mathrm{Z}_{\mathrm{B}}+$ töltésű $\mathrm{Me}_{\mathrm{B}}$ ion is adszorbeálódhat:

$$
\mathrm{S}+\mathrm{Me}_{\mathrm{B}}^{\mathrm{zB}+} \rightleftharpoons \mathrm{Me}_{\mathrm{B}}^{\mathrm{zB}+}-\mathrm{S}
$$


Az ioncsere viszont már egy borított felületeken lejátszódó szubsztitúciós reakció:

$\mathrm{z}_{\mathrm{B}} \mathrm{Me}_{\mathrm{A}}{ }^{\mathrm{zA}+}+\mathrm{z}_{\mathrm{A}} \mathrm{Me}_{\mathrm{B}}{ }^{\mathrm{zB}+}-\mathrm{S} \rightleftharpoons \mathrm{z}_{\mathrm{A}} \mathrm{Me}_{\mathrm{B}}{ }^{\mathrm{zB}+}+\mathrm{z}_{\mathrm{B}} \mathrm{Me}_{\mathrm{A}}{ }^{\mathrm{zA}+}-\mathrm{S}(3)$

Az adszorpciót (4), a kompetitív adszorpciót (5) és az ioncserét (6) leíró izoterma-egyenletek rendre:

$$
\begin{gathered}
c / a=(c+K) / z \\
c_{A} / a_{A}=\left(c_{A}+K_{A}+K_{A} c_{B} / K_{B}\right) / z \\
c_{A} / a_{A}=\left(c_{A}+K_{A} c_{B} / K_{B}\right) / z
\end{gathered}
$$

ahol $c$ a szorbeálódó anyag koncentrációja az egyensúlyi oldatban, $a$ az egységnyi felületen felhalmozódott anyagmennyiség, $z$ a felületi aktív helyek száma (maximális kapacitás), $K$ a megkötés erősségét jellemző paraméter.

A kompetitív adszorpció és az ioncsere izotermák közötti látszólag kicsi különbségre ( $K_{A}$ az (5) egyenlet jobb oldalán) Boyd és munkatársai ${ }^{6}$ már 1947-ben felfigyeltek, ezt azonban csak matematikai elhanyagolással értelmezték. A (6) ioncsere izoterma a tömeghatás törvényéből levezethető ${ }^{7-10}$. Homovalens kationcsere egyensúlyi állandója:

$$
K_{B, A}=\left(a_{A} * c_{B}\right) /\left(a_{B} * c_{A}\right)
$$

Ioncsere esetén minden cserehely $(z)$ betöltött, vagyis

$$
z=a_{A+} a_{B}
$$

Innen az $\mathrm{a}_{\mathrm{B}}$-t kifejezve és behelyettesítve a (7)-be kapjuk:

$$
K_{B, A}=\left(a_{A} * c_{B}\right) /\left(\left(z-a_{A}\right) * c_{A}\right)
$$

Ekvivalens matematikai átalakítások után:

$$
c_{A} / a_{A}=\left(c_{A}+c_{B} / K_{B, A}\right) / z \text { és } K_{B, A} K_{B} / K_{A}
$$

Tehát a (6) egyenlettel megegyező egyenlethez jutottunk, ami igazolja, hogy az ioncsere izoterma és a tömeghatás törvénye egymásba átalakítható. Hasonlóan elvégezhetők a heterovalens ioncserére vonatkozó átalakítások is.

\section{Kalcium-nátrium ioncsere}

Az agyagásványok rétegközi terében domináns kicserélhető kationként leggyakrabban a nátrium- vagy a kalciumion fordul elő. Ha az agyag tengervízben keletkezik, akkor nyilván a nátriumionok vannak döntő többségben. A felszín alatti vizekkel érintkezve azonban ezek könnyen kicserélődnek kalciumionokra, mivel a kétértékü kalciumion erősebben kapcsolódik a negatív rétegtöltéshez, mint az egyértékű nátriumion. A Kárpát-medencei bentonitelőfordulások uralkodó kationja a kalciumion.

A nátrium- és a kalcium-kationcsere hatását legszembeszökőbben a talajoknál tapasztaljuk ${ }^{11}$. A nátriumionban gazdag szikes talajok termőképessége messze elmarad a kalciumiont tartalmazó, például mezőségi talajoktól. Ennek oka a két forma duzzadóképességében keresendő. Míg száraz állapotban a Na-montmorillonit rétegközi tere vízmolekula-réteget tartalmaz, addig a Ca-montmorillonité kettőt. Ha azonban korlátlanul áll rendelkezésre víz, akkor a nátrium-montmorillonit akár száraz térfogatának több mint tízszeresére is duzzadhat. A kalciumionoknál a kétértékü ionok és a rétegtöltés erősebb elektrosztatikus vonzása miatt ez az érték jóval kisebb, mindössze kétszeres-háromszoros érték. A nátrium-montmorillonitnak ez a nagymértékü duzzadása, ill. kiszáradása okozza a szikes talaj repedezését, ill. vízzáróvá teszi azt. Ugyanakkor a duzzadás következtében a rétegek eltávolodnak egymástól, az elektrosztatikus térerősség erősen lecsökken, a rétegek egymáson elcsúszhatnak, önterülö tulajdonságot tapasztalunk. A nátriumiont tartalmazó agyagok vizes környezetben csúsznak, amit az építkezéseknél célszerü figyelembe venni.

Az egyes felhasználásoknál a nátrium-kalcium-agyagok közti különbségeket hasznosítják. Például a nátriumbentonit vízzáró tulajdonsága miatt hulladéktárolók szigetelőrétegeként alkalmazzák. Ha a helyben előforduló agyag kalcium-formájú, akkor szódázással, vagyis nátrium-karbonát adagolásával a kalcium-karbonátot kicsapják, a rétegközi térbe így nátriumionok kerülnek. Ugyanígy készítik elő a fúróiszapként használt agyagot is, ahol a rétegek csúszását, a képlékenységet használják ki.

\section{Egyéb kationok cseréje}

Kutatásaink során számos kationcserélt montmorillonitot elöállítottunk $^{12-30}$, melyek közül néhánynak a fényképét a 2. ábrán mutatjuk be.

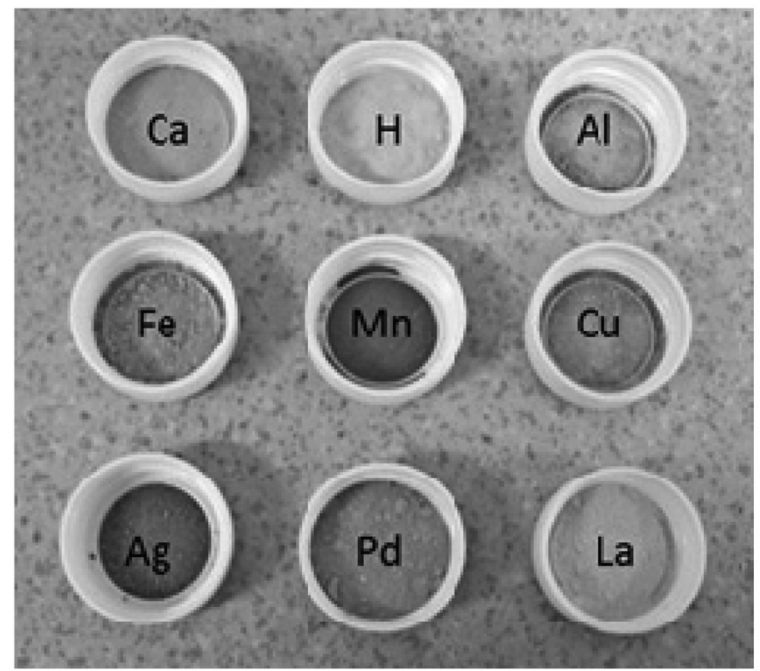

2. Ábra. Kationcserélt bentonitok

A talajok, ill. bentonit domináns ionjain $\left(\mathrm{Na}^{+}-, \mathrm{Ca}^{2+}\right.$-ion) kívül esszenciális mikroelemek $\left(\mathrm{Mn}^{2+}, \mathrm{Zn}^{2+}, \mathrm{Cu}^{2+}, \mathrm{Fe}^{3+}\right.$, $\left.\mathrm{Co}^{2+}\right)$, geológiai indikátorok $\left(\mathrm{Y}^{3+}\right.$, lantanoidaionok), és szennyező ionok $\left(\mathrm{Pb}^{2+}, \mathrm{Cd}^{2+}, \mathrm{Hg}^{2+}, \mathrm{Ag}^{+}, \mathrm{Pd}^{2+}\right)$, radioaktív szennyező ionok $\left({ }^{22} \mathrm{Na}^{+},{ }^{134,137} \mathrm{Cs}^{+},{ }^{45} \mathrm{Ca}^{2+},{ }^{85} \mathrm{Sr}^{2+},{ }^{90} \mathrm{Sr}^{2+}\right.$, $\left.{ }^{60} \mathrm{Co}^{2+},{ }^{212} \mathrm{~Pb}^{2+},{ }^{36} \mathrm{Cl}^{-},{ }^{131} \mathrm{I}^{-}\right)^{31-33}$ kationcseréjét vizsgáltuk. Előállítottunk várhatóan katalitikus hatást mutató kationcserélt bentonitokat $\left(\mathrm{H}^{+}, \mathrm{Fe}(\mathrm{III}), \mathrm{Zn}^{2+}, \mathrm{Cu}^{2+}\right.$, Mn(II,IV), Ce(III,IV), Pd(0,II)) 24, 34 . A koncentrációmérést általában radioizotópos nyomjelzős módszerrel végeztük, amely nagy érzékenysége miatt az igen kis koncentrációk (hordozómentes oldatok) használatát is lehetővé teszi. 
A kationcsere tanulmányozása lehetővé teszi a kőzetekben, talajokban lejátszódó folyamatok vizsgálatát, információt adnak a kationok kémiai állapotáról, szorpciós és transzport-folyamatairól, az agyag szerkezetének változásáról a kationcsere hatására, illetve megteremtik annak lehetőségét, hogy megvizsgáljuk, milyen kémiai reakciók mennek végbe a montmorillonit rétegközi terében.

\section{Az agyagok mint szigetelőrétegek}

Mint a 3. fejezetben már említettük, a bentonitot használják hulladéktárolók ágyazati rétegeként. Jó vízzáró tulajdonsága miatt a nátrium-bentonitot részesítik előnyben. A nagy aktivitású nukleáris hulladék tárolásánál lehetőségként merül fel a bentonit alkalmazása. Ennél a hulladéktípusnál azonban a zárórétegnek több tízezer évig kellene biztosítani azt, hogy a radioaktív nuklidok ne kerüljenek kölcsönhatásba a bioszférával. Ilyen hosszú idő távlatában elképzelhetetlennek tünik, hogy a bentonit ne nedvesedjen át és ne szorbeálja a felszín alatti vizekben és a nukleáris hulladékban levő két-, ill. háromértékü kationokat is.

Az agyagok szigetelő tulajdonságát első közelítésben a pórusrendszer, ill. nedves állapotban az abban levő vízformák aránya határozza meg. Bentonitban háromféle vizet különböztetünk meg ${ }^{35}$ :

- a montmorillonit rétegközi terében levő víz, tartalmazza a permanens negatív töltést semlegesítő kicserélhető kationokat; az anionok innen kizáródnak

- a szemcsék külső felületein levő elektromos kettősréteg vize, amelyben dominálnak a kationok

- szabad pórusvíz: kationok és anionok ekvivalens mennyiségben találhatók.

$\mathrm{Az}$ anionok és a kationok eltérő úton mozognak a bentonitban: a kationok mindhárom víztípusban jelen lehetnek, az anionok viszont lényegében kizáródnak a rétegközi vízből és az elektrosztatikus kettős réteg vizében is kisebb a koncentrációjuk, mint a kationoké. A bruttó migrációs együttható a háromféle pórusban való migrációból adódik össze ${ }^{36}$ :

$$
D_{\text {tot }}=x_{p} g_{p} D_{p}+x g_{s} D_{s}+x_{i} g_{i} D_{i}
$$

ahol $\mathrm{x}_{\mathrm{p}}, \mathrm{x}_{\mathrm{s}}$ és $\mathrm{x}_{\mathrm{i}}$ a migráló ion relatív mennyisége az adott útvonalon, $g_{p}, g_{s}$ és $g_{i}$ az útvonalak geometriai faktorai, $D_{p}$, $D_{s}$ és $D_{i}$ az ionok látszólagos migrációs együtthatói az útvonalakon, $\mathrm{p}, \mathrm{s}$ és i jelentik a pórusvizet, a külső felületeken, ill. a rétegközi térben levő vizet. Anion esetén a rétegközi teret kizárják: $\mathrm{x}_{\mathrm{i}}=0$.

Ezen kívül a kationok kicserélődhetnek a montmorillonit rétegközi terében levő kationokkal, mozgási sebességük ebből kifolyólag csökken.

Mivel a rétegközi kation minősége nagy hatással van a montmorillonit duzzadására, ebből következően a vízformák arányára is. Az utóbbi időkben több közlemény foglalkozik a vízformák arányát befolyásoló tényezőkkel, az anionok és a kationok migrációja közötti különbségekkel nátriumbentonitban. A migrációs modellek a száraz bentonit porozitását $(\varepsilon)$ és sürüségét $(\rho)$, valamint a migráló kation megoszlási együtthatóját $\left(K_{d}\right)$ alkalmazzák. A látszólagos migrációs együttható $\left(D_{a}\right)$ kifejezése kationra ${ }^{37}$ ill. anionra $^{38}$ :

$$
\begin{gathered}
D_{a}=\varepsilon \Psi D_{0} /\left(\varepsilon+\rho K_{d}\right) \\
D_{a}=\varepsilon D_{p=} \varepsilon D_{0} / \Phi^{2}
\end{gathered}
$$

ahol $D_{0}$ az ion diffúziós együtthatója tiszta vízben, $\Psi$ alaktényező, $\Phi$ bolyongási tényező, $\mathrm{D}_{\mathrm{p}}$ az ion diffúziós együtthatója a pórusvízben.

A reális, sőt már a laboratóriumi kísérleti rendszerekben is a bentonit nedves, a rétegközi nátriumionok pedig egyéb, nagyobb töltésü kationra cserélödhetnek. Az 1. táblázat a klorid- és a céziumion migrációs együtthatóit mutatja be különböző rétegközi kationt $\left(\mathrm{Na}^{+}, \mathrm{Ca}^{2+}-, \mathrm{Fe}^{3+}\right.$, lantanoidaionok) tartalmazó bentonitban.

\begin{tabular}{lll}
\hline & $\mathrm{D}_{\mathrm{a}}\left(\mathrm{m}^{2} / \mathrm{s}\right)$ & \\
\hline & $\mathrm{Cl}^{-}$ & $\mathrm{Cs}^{+}$ \\
Na-bentonite & $1.15 \mathrm{E}-11$ & $3.07 \mathrm{E}-13$ \\
Ca-bentonite & $6.32 \mathrm{E}-12$ & $3.07 \mathrm{E}-13$ \\
Fe(III)-bentonite & $4.30 \mathrm{E}-12$ & $9.27 \mathrm{E}-13$ \\
Mean of seven rare earth bentonites & $5.34 \mathrm{E}-12$ & $2.28 \mathrm{E}-13$ \\
\hline
\end{tabular}

1. Táblázat. Klorid- és a céziumion migrációs együtthatóit mutatja be különböző rétegközi kationt $\left(\mathrm{Na}^{+}, \mathrm{Ca}^{2+}-, \mathrm{Fe}^{3+}\right.$, lantanoidaionok) tartalmazó bentonitban (a migrációs együttható hibája $\pm 10 \%)^{39}$

Az 1. táblázat adataiból látható, hogy a kicserélhető kation elsősorban a kloridionok migrációjára van hatással, mivel nátrium-bentonitban a montmorillonit duzzadása lényegesen nagyobb mértékü, megnő a rétegközi víz aránya. A rétegek nagy távolsága miatt a rétegek közötti az elektrosztatikus térerősség lecsökken, tehát már nem tartható fent az a közelítés, hogy az anionok a rétegközi térből teljesen kizáródnak. A nagy víztérfogat miatt változik az ionerősség és ezzel az elektromos kettősréteg vastagsága/térfogata, az ionok eloszlása az elektromos kettősrétegben. A kloridion migrációs együtthatója a nátrium-bentonitban mintegy kétszerese az egyéb kationcserélt bentonitban mért értékeknek. Tehát nedves állapotban a nátrium-bentonit szigetelőképessége az anionokat tekintve kedvezőtlenebb.

A céziumion szorpciós erőssége a bentonit felületén olyan nagy $\left(\mathrm{K}_{\mathrm{Cs}, \mathrm{Ca}} \sim 30\right)$, hogy felülírja az egyéb hatásokat. Kivételt képez a $\mathrm{Fe}$ (III)-bentonit, ahol a rétegközi térben kialakuló oxid-, hidroxid-réteg eltömi a rétegközi teret ${ }^{22,23}$, ezáltal csökkentve a céziumion szorpcióját. 


\section{Reakciók a rétegközi térben}

\subsection{Katalitikus hatások}

Az agyagok felületén lejátszódó szorpció következtében a molekula szerkezete és kémiai kötése megváltozhat, ami katalitikus hatást idézhet elő. Az agyagásványok sok szerves reakcióban katalizátorként vesznek részt, gyakran termék-, alak- és regioszelektivitást mutatnak. A reakciókörülmények enyhék, a katalizátor szüréssel elválasztható, nincs szüksége szerves oldószerek használatára. Így alkalmasak az ún. zöld kémiai eljárásokban.

A katalitikus aktivitás fő oka a Brönsted- és Lewis-savasság. A Brönsted-savasság a terminális hidroxil-csoportoktól és a híd oxigénektől ered. A savi erősség a kicserélhető kationok minőségével változik, mivel a rétegközi kationokhoz koordinált vízmolekulák disszociációja erős Brönstedsavasságot okoz. A Lewis-savasság oka a nem teljesen koordinált $\mathrm{Al}^{3+}$ - és $\mathrm{Fe}^{3+}$-ionok jelenléte a rácsszéleken. A savasságra gyakorolt hatáson kívül a rétegközi térben, sőt a kristályrácsban levő kationok is különböző oxidációs állapotban lehetnek jelen (pl. $\mathrm{Fe}^{2+}$ vagy $\mathrm{Fe}^{3+}, \mathrm{Mn}^{2+}$ vagy $\left.\mathrm{Mn}(\mathrm{IV})^{22-24,40}\right)$, tehát redoxreakciókat is katalizálhatnak. A rétegközi térbe kationcserével bevihetők a szerves kémiában használt sók kationjai ( $\mathrm{pl} . \mathrm{Zn}^{2+}$ ), amelyek szokásos hatásukat ott is kifejtik.

Az agyagkőzeteket természetes vagy módosított formában egyaránt alkalmazzák ${ }^{41-47}$. A kémiai módosítások fő célja a katalitikus aktivitás növelése. Egyik formája a savas kezelés, mely a rács roncsolása révén a rácsszéli, nem teljesen koordinált ionok mennyiségét növeli. Másik lehetőség a már említett kationcsere folyamat. A szervetlen ionokon kívül szerves kationok (tenzidek, polimerek) is beépíthetők a rétegközi térbe, amelyek méretüktől és a rétegközi térben való elhelyezkedésüktől függően a rétegeket egymástól eltávolítják. Ha fém-oxigén láncok képzésére (is) alkalmas kationt (pl. aluminium-. cirkónium, króm-, vas-, lantanoida-ionok, fémorganikus komplexek) viszünk a rétegközi térbe, majd a mintákat hőkezeljük, akkor kapjuk a mikro- vagy mezopórusos szerkezetü pillérezett agyagokat ${ }^{48}$.

Kationcserélt bentonit katalitikus hatását a 1,1-diacetálok előállítására aromás aldehidekből a Zn-bentonit esetén mutatjuk be ${ }^{34}$ :

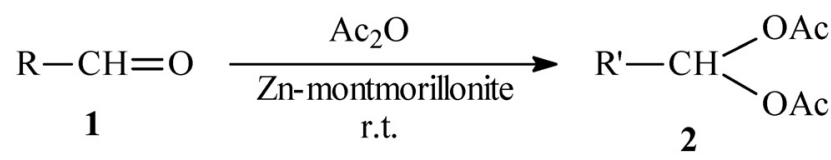

2. Táblázat. Aldehid-1,1-diacetátok (2) eloállítása aromás aldehidekbol (1) Zn-bentonit katalizátorral ${ }^{34}$

\begin{tabular}{|c|c|c|c|c|c|}
\hline Szubsztrát & Termék & Idö & $\begin{array}{l}\text { Ho- } \\
\text { zam }\end{array}$ & Olvadásp & ont. ${ }^{\circ} \mathrm{C}$ \\
\hline $\mathrm{R}$ & $\mathrm{R}^{\prime}$ & $\mathrm{h}$ & $\%$ & kísérleti & közölt \\
\hline $\mathrm{Ph}$ & $\mathrm{Ph}$ & 24 & $>99$ & $43-43.5$ & $43-45$ \\
\hline $2-\mathrm{HOC}_{6} \mathrm{H}_{4}$ & 2- $\mathrm{AcOC}_{6} \mathrm{H}_{4}$ & 96 & $>99$ & $101-103$ & $\begin{array}{l}103- \\
104\end{array}$ \\
\hline $4-\mathrm{HOC}_{6} \mathrm{H}_{4}$ & $4-\mathrm{AcOC}_{6} \mathrm{H}_{4}$ & 48 & $>99$ & $89-90$ & 93-95 \\
\hline $3-\mathrm{HOC}_{6} \mathrm{H}_{4}$ & $3-\mathrm{AcOC}_{6} \mathrm{H}_{4}$ & 24 & $>99$ & $82-83$ & \\
\hline $2,4-(\mathrm{HO})_{2} \mathrm{C}_{6} \mathrm{H}_{3}$ & $2,4-(\mathrm{AcO})_{2} \mathrm{C}_{6} \mathrm{H}_{3}$ & 24 & & & 148 \\
\hline $3,4-(\mathrm{HO})_{2} \mathrm{C}_{6} \mathrm{H}_{3}$ & $3,4-(\mathrm{AcO})_{2} \mathrm{C}_{6} \mathrm{H}_{3}$ & 48 & $>99$ & $128-130$ & 131 \\
\hline $4-\mathrm{MeOC}_{6} \mathrm{H}_{4}$ & 4- $\mathrm{MeOC}_{6} \mathrm{H}_{4}$ & 120 & $>99$ & & $64-65$ \\
\hline $4-\mathrm{BrC}_{6} \mathrm{H}_{4}$ & $4-\mathrm{BrC}_{6} \mathrm{H}_{4}$ & 96 & $>99$ & $92-95$ & \\
\hline $4-\mathrm{O}_{2} \mathrm{NC}_{6} \mathrm{H}_{4}$ & $4-\mathrm{O}_{2} \mathrm{NC}_{6} \mathrm{H}_{4}$ & 72 & $>99$ & $118-121$ & 125 \\
\hline
\end{tabular}

\subsection{Redoxfolyamatok és hidrolízis}

A rétegközi térben levő kationok a levegő oxigénjével reagálva oxidálódhatnak, illetve a rétegközi tér vizével hidrolizálhatnak. Előbbire példa a Mn(II)-ionok lassú átalakulása hármas és négyes oxidációs állapotúvá, melyet szemléletesen mutat a mangán-bentonit megbarnulása ${ }^{22,40}$ (3. ábra).

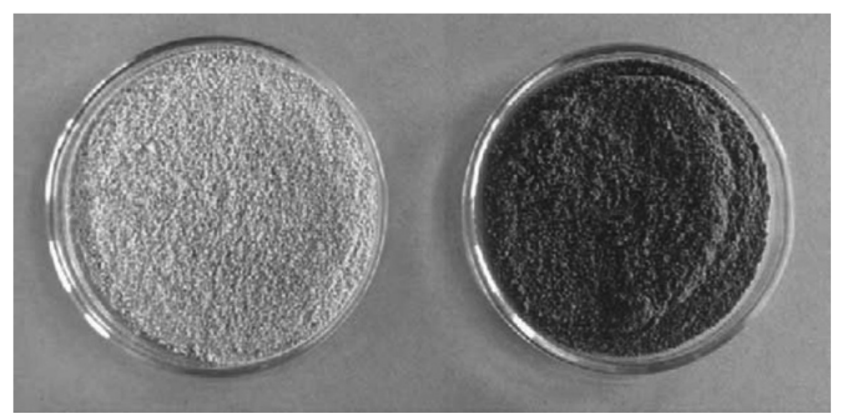

3. Ábra. Friss és régi mangán-bentonit

A hidrolitikus folyamat a vas(III)-ion esetén figyelhető meg, amelynek bevitele a rétegközi térben már maga is problematikus. Mint az jól ismert, a vas(III)-ionok csak viszonylag savas $\mathrm{pH}-\mathrm{n}$ tarthatók meg hidratált ionként; ekkor azonban az agyag szerkezete roncsolódik. Ha azonban vas(III)-sót acetonban oldunk és ezt az oldatot reagáltatjuk a bentonittal, akkor a rétegközi kationokat vas(III)-ionokra cserélhetjük. A rétegek között azonban víz van, így a vas(III)-ionok ott is hidrolizálnak és oxid-hidroxid nanoréteget képeznek. Ennek jelenlétét Mössbauerspektrum igazolja, melyben a megjelenő szextet aleagalább a Kurie-cellának megfelelö méretü vas(III)-oxid-hidroxid nanorészecskékre utal ${ }^{23,24}$ (4. Ábra). 


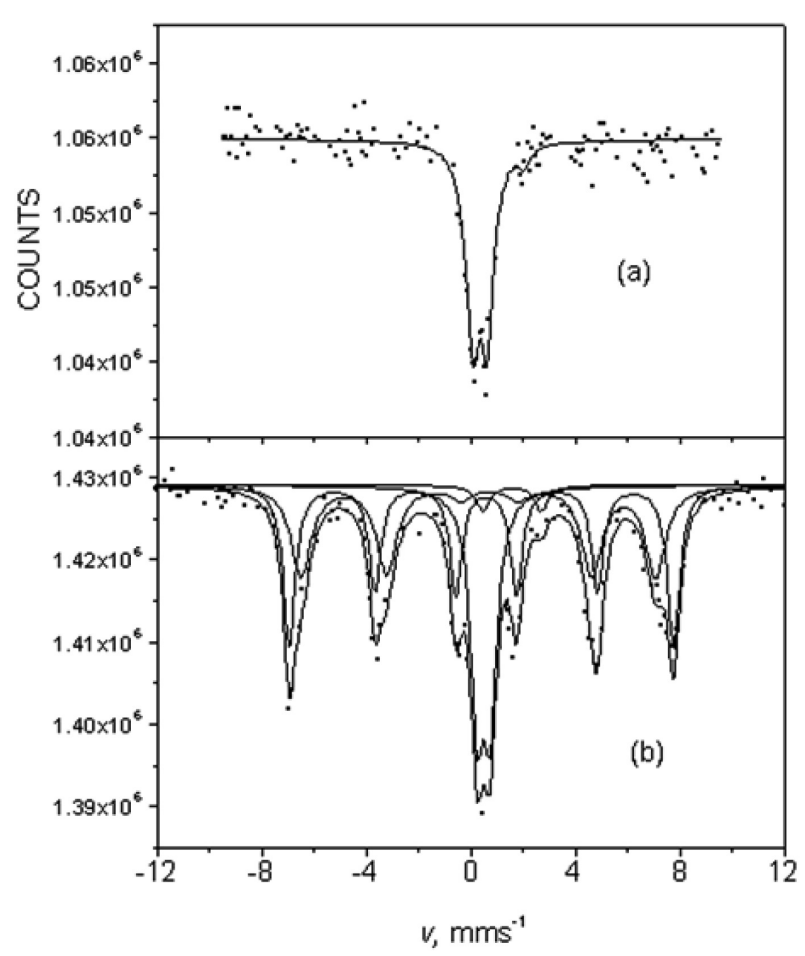

4. Ábra. Bentonit Mössbauer spectrumai ( $74 \mathrm{~K}) \mathrm{FeCl} 3$ acetonos oldatával való kezelés előtt(a) és után (b)

\subsection{Csapadékképződés a rétegközi kationokkal}

Ha a rétegközi tér olyan kationt tartalmaz, amely a vele érintkező oldatban levő anionnal csapadékot képez, akkor az oldatból az anion megköthetö. Ennek példája a lantán-bentonit alkalmazása foszfátion megkötésére, és ezzel a vizek eutrofizációjának csökkentésére.

\section{Az ioncsere különleges esete: heterogén izotópcsere}

Létrehozhatunk ioncserét úgy is, hogy a két cserélő ion ugyanazon elem eltérő tömegszámú izotópja, ill. összetett ion esetén ilyet tartalmaz. Ilyenkor kémiai folyamat nincs, a csere szabadentalpia változását egyedül az elegyedési entrópia növekedése adja. Egyensúlyi folyamatok igen kis mennyiségü radioaktív indikátor segítségével úgy vizsgálhatók, hogy az egyensúlyt nem zavarjuk meg.

A talajok tápanyagforgalmát alapvetően befolyásolja a talajoldatban levő makro- és mikrotápanyagok koncentrációja, amelyet a talaj szilárd fázisa és a talajoldat közötti kölcsönhatások határoznak meg. Ezek a kölcsönhatások döntőek lehetnek egy olyan tápanyag esetén, mint a foszfátion, amely erősen kötődik bizonyos talajalkotókhoz; csapadékot képez különböző kationokkal és reagál a talaj szerves alkotórészeivel (5. ábra). A foszfát és bizonyos talajalkotók reakciói lassúak, steady-state állapotra vezetnek. Ilyen állapotban a talajalkotók és a talajoldat kölcsönhatásai, a talajoldat foszforkoncentrációja és kövezésképpen a foszfáttrágyák hatékonysága a foszfát kémiai állapotainak megoszlásától függ. Az optimális trágyázás feltétele a vízoldható/kicserélhető foszfát mennyiségének, valamint a foszfát deszorpció- ill. cseresebességének ismerete a talaj és a talajoldat között steady-state állapotban. A heterogén izotópcsere folyamatban a gyengén kötött, kicserélhető foszfátion-mennyisége meghatározható, valamint a steady-state csere sebessége ${ }^{49}$.
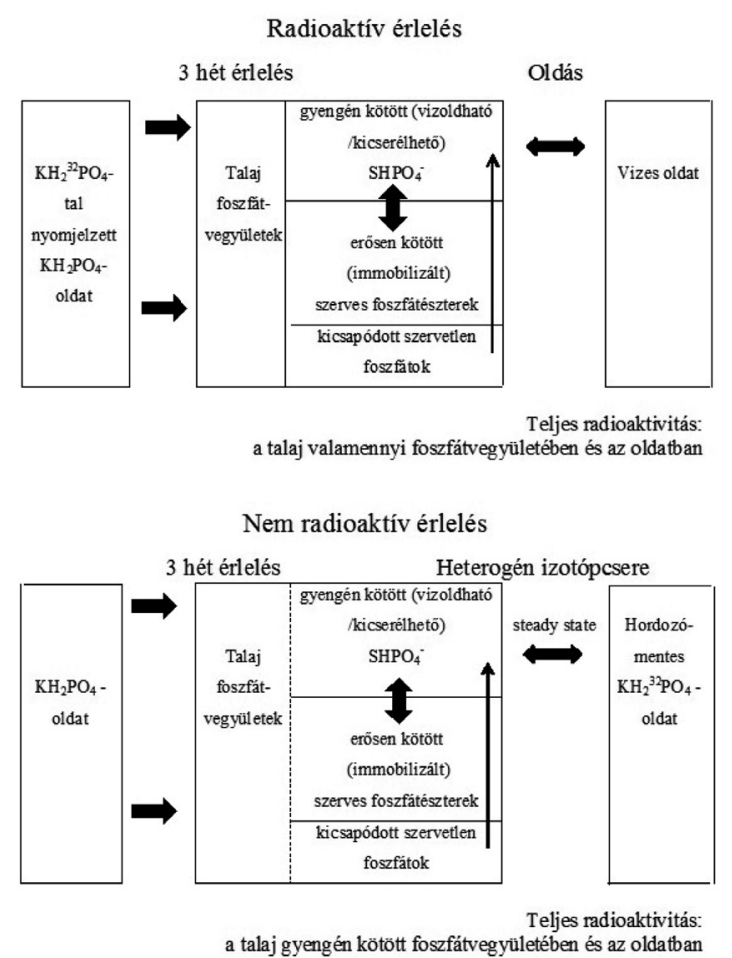

5. Ábra. Foszfátionok reakciói talaj radioaktív és inaktív foszfátionokkal való érlelés során, valamint az azt követő oldási és heterogén izotópcsere folyamatban $^{49}$

\section{Az agyagásvány rácsszerkezetének átalakulása a kationcsere következtében}

A kationcsere következtében a rétegközi tér mérete és a rács szerkezete egyaránt megváltozhat.

A rétegközi tér változása röntgendiffracióval, a d(001) bázislap megváltozásán keresztül követhető. Az egyértékü kationok esetén légszáraz állapotban a montmorillonit rétegközi térben egy molekularéteg víz található. Ilyenkor kb. 1,2 nm bázislap-távolságot mérünk. Kétértéű ionok esetén a vízrétegek száma kettő, a jellemző bázislap-távolság 1,5 nm. Háromértékü ionok (Fe(III), $\mathrm{Al}(\mathrm{III})$, ritkaföldfémionok) estén ez az érték kicsit nagyobb, 1,6 nm-ig is megnőhet és függ a kation sugarától. A 6. ábrán a ritkaföldfém-montmorillonitok bázislap távolságát mutatjuk be a lantanoida kation sugarának függvényében.

Izgalmas kérdés, hogy a kationcsere milyen hatással van az aluminoszlikát vázra. Talajkémiában ismert, hogy káliumionok cseréjének hatására a montmorillonit illitté alakul át, ami azért következik be, mert a káliumionok beférnek a rács üres helyeire, ezáltal ott fixálódnak, a kationcsere-képesség erősen lecsökken. Hasonló jelenséget figyeltek meg lítiumionok esetén is.

Újabb kutatásaink azt mutatták, hogy a háromértékű ritkaföldfém-ionok közül a lantán-, a cérium- és a gadolíniumion esetén a kationcsere-kapacitást meghaladó 
mennyiségü szorpció történik, tehát a rétegközi téren túl más kötőhelynek is lenni kell. Ezzel egy időben a Mössbauer spektrumban olyan mágneses felhasadás fordul elö, ami a rétegközi térben vas-oxid-hidroxid jelenlére utal (7. ábra $)^{30}$. Mivel a természetes kalcium-bentonitban ilyet nem tapasztalunk, feltételezzük, hogy a rács oktaéderes pozícióiból kerülhet át a vas a rétegközi térbe.

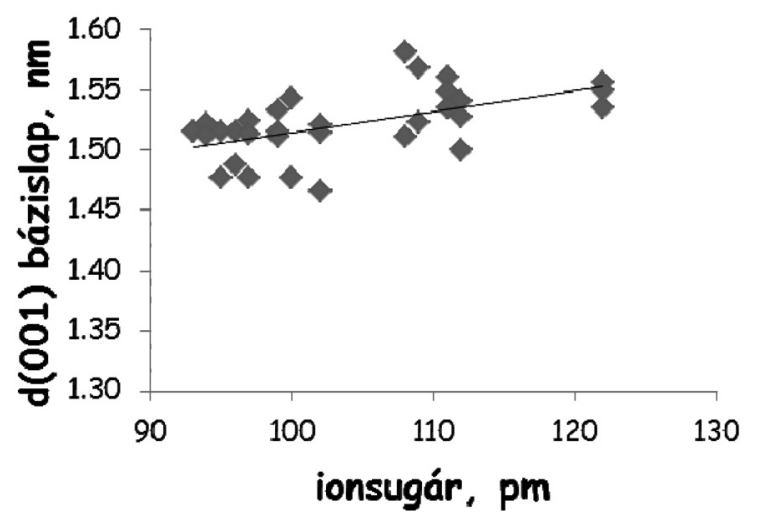

6. Ábra. A ritkaföldfém-montmorillonitok bázislap távolsága a lantanoida kation sugarának függvényében

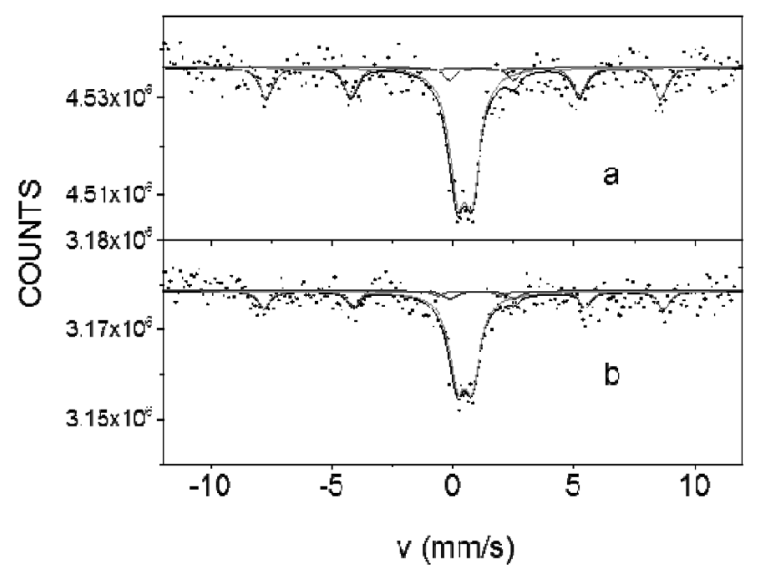

7. Ábra. Lantán-bentonitok 78K-en felvett Mössbauer-spektrumai. La-tartalom: $3.9 \times 10-4 \mathrm{~mol} / \mathrm{g}$ (a) és $2.9 \times 10-4 \mathrm{~mol} / \mathrm{g} \mathrm{(b)}$

\section{Köszönetnyilvánítás}

Köszönetet mondok mindazoknak a munkatársaknak, akik ezekben a kutatásokban segítettek: Kuzmann Ernőnek, Földvári Máriának, Kovács-Pálffy Péternek, Kónya Péternek, Kristály Ferencnek, Beszeda Imrének, Kálmán Erikának, Papp Katalinnak, Keresztes Zsófiának, Antus Sándornak, Jakab Mártának, Papp Istvánnak, Baranyai Edinának, Kovács Eszter Máriának, Buzetzky Dórának, Molnár Ákos Máténak, és még sok-sok kedves hallgatómnak. Külön köszönet illeti Kónya Józsefet, akivel már több mint három évtizede dolgozunk együtt.

\section{Összefoglalás}

A rétegrácsos szilikátok egyik meghatározó tulajdonsága az ioncserélö-képesség. Ez akkor jelentős mértékü, ha az aluminoszilikát-kristályrácsban olyan izomorf helyettesítések vannak, amelyek a szerkezetnek állandó negatív rétegtöltést adnak. Egyik legfontosabb képviselöjük a montmorillonit agyagásvány, melyben a rétegközi tér „nanolaboratóriumában” jelenlevő kationok cseréje, és az ezt kísérő kémiai reakciók alapvető szerepet játszanak az elöfordulás helyén és felhasználásukban egyaránt.

Közleményünkben bemutatjuk az ioncsere reakciók kezelésének új termodinamikai szemléletét; az ioncsere hatását a mechanikai, duzzadási és migrációs tulajdonságokra; az ioncsere szerepét a montmorillonittartalmú kőzet, a bentonit pórusrendszerére és az ionok migrációjára, amely a hulladéktárolók szigetelőképességének kulcskérdése; az agyagok katalitikus hatását, annak módosítását kationcsere-folyamatokkal; a rétegközi térben levő ionok oxidációs, hidrolitikus reakcióit, a kationcserélt agyagok használatát anionok megkötésére; a kationcserét kísérő szerkezeti változásokat; illetve az ioncsere különleges formájának, a heterogén izotópcserének a felhasználását a talajok foszforforgalmának vizsgálatában.

\section{Hivatkozások}

1. Thomson, H.S. J. Royal Agricult. Soc. Engl. 1850, 11, 68.

2. Way, J.T. Royal Agricult. Soc. Engl. 1850, 11, 313.

3. Way, J.T. Royal Agricult. Soc. Engl. 1852, 13, 123.

4. Way, J.T. Royal Agricult. Soc. Engl. 1855, 15, 491.

5. Bergaya, F., Theng, B.K.G., Lagaly, G. (eds) Handbook of clay science, $3^{\text {rd }}$ ed.,Elsevier, Amsterdam 2008.

6. Boyd, G. E., J. Schubert, and A. W. Adamson. J. Am. Chem. Soc. 1947 69, 2818-2829. https://doi.org/10.1021/ja01203a064

7. Nagy, N.M., Kónya. J. Interfacial chemistry of rocks and soils, Taylor and Francis, 2009. https://doi.org/10.1201/9781420091335

8. Kónya, J., Nagy, N.M. Per. Pol. Chem. Eng. 2009, 53, 55-60. https://doi.org/10.3311/pp.ch.2009-2.04

9. Kónya, J., Nagy, N.M.: Adsorption 2013, 19,701-707. https://doi.org/10.1007/s10450-013-9495-6

10. Nagy, N.M., Kovács, E. M., Kónya, J. Radioanal. Nucl.Chem. 2016, 308, 1017-1026. https://doi.org/10.1007/s10967-015-4536-0

11. Kónya J., Filep Gy. Agrokémia és Talajtan 1975, 24, 382-394,1978, 27, 65-76, 1978, 27, 345-356.

12. Földvári, M., Kovács-Pálffy, P., Nagy, N.M., Kónya, J. J. Thermal Analysis 1998, 53, 547-558. https://doi.org/10.1023/A:1010105828289

13. Nagy, N.M., Kónya, J. Colloids and Surfaces 1988, 32,223-235. https://doi.org/10.1016/0166-6622(88)80018-0

14. Kónya, J., Nagy, N.M., Szabó, K. Reactive Polymers 1988 , 7, 203-209. http://dx.doi.org/10.1016/0167-6989(88)90141-9

15. Kónya, J., Nagy, N.M., Högfeldt, E. Acta Chem.Scand. 1989,43, 612-614. DOI: 10.3891/acta.chem.scand.43-0612

16. Kónya, J., Nagy, N.M. Colloids and Surfaces 1998, 136, 297-308. http://dx.doi.org/10.1016/S0927-7757(97)00362-2 
17. Kónya, J., Nagy, N.M., Király, R., Gelencsér, J. Colloids and Surfaces 1998, 136, 309-317. http://dx.doi.org/10.1016/S0927-7757(97)00363-4

18. Nagy, N.M., Kónya, J. Colloids and Surfaces 1998, 137, 231- 242. https://doi.org/10.1016/S0927-7757(97)00381-6

19. Szántó, Zs., Papp, L., Kónya, J., Nagy, N.M., Lengyel, Zs. J. Radioanal. Nucl. Chem. 1999, 241, 45-49. https://doi.org/10.1007/BF02347288

20. Nagy, N. M., Kónya, J. Reactive Polymers 1992, 17, 9-13. http://dx.doi.org/10.1016/0923-1137(92)90564-I

21. Nagy, N. M., Kónya, J., Budai, T. Colloids and Surfaces 1998, 138, 81-89. https://doi.org/10.1016/S0927-7757(97)00383-X

22. Nagy, N.M., Komlósi, A., Kónya, J. J.Coll.Interface Sci. 2004, 278, 166-172. https://doi.org/10.1016/j.jcis.2004.05.035

23. Komlósi, A., Kuzmann, E., Homonnay, Z., Nagy, N.M., Kubuki, S., Kónya, J. Hyperfine Interactions 2006, 166, 643-649. https://doi.org/10.1007/s10751-006-9335-0

24. Komlósi, A., Kuzmann, E., Homonnay, Z., Nagy, N.M., Kubuki, S., Kónya, J. Clays Clay Miner. 2007, 55, 91-97 https://doi.org/10.1346/CCMN.2007.0550107

25. Kónya, J. Nagy, N.M. J. Radioanal. Nucl. Chem. 288 (2011) 447-454 https://doi.org/10.1007/s10967-010-0968-8

26. Nagy, N.M., Kónya, J., Urbin, Z. Colloids and Surfaces 1997, 121, 117-123. https://doi.org/10.1016/S0927-7757(96)03844-7

27. Nagy, N. M., Kónya, J., Kónya, I. Colloids and Surfaces 1998, 137, 243-252. https://doi.org/10.1016/S0927-7757(98)80006-X

28. Nagy, N. M., Kónya, J., Beszeda, M., Beszeda, I., Kálmán, E., Keresztes, Zs., Papp, K. Proc. Colloid Polym.Sci. 2001, 117, 117-19.

29. Nagy, N. M., Kónya, J., Beszeda, M., Beszeda, I., Kálmán, E., Keresztes, Zs., Papp, K. J. Coll. Interface Sci. 2003, $263,13-22$. https://doi.org/10.1016/S0021-9797(03)00284-4

30. Kuzmann, E., Singh, L. H., Garg V. K., de Oliveira, A. C., Kovács, E. M., Molnár, A. M., Homonnay, Z., Kónya, P., Nagy, N. M., Kónya, J. Hyperfine Interact. 2016, 237, 1-8. https://doi.org/10.1007/s10751-016-1225-5

31. Nagy, N. M., Kónya J., Wazelischen-Kun, Gy. Colloids and Surfaces 1999, 152, 245-250. https://doi.org/10.1016/S0927-7757(98)00832-2

32. Nagy, N.M., Kónya, J., Földvári, M., Kovács-Pálffy, P. Czech J. Phys. 2003, 53, A103-111. https://doi.org/10.1007/s10582-003-0016-9
33. Nemes, Z., Nagy, N.M., Kónya, J. J. Radioanal. Nucl. Chemistry 2005, 266, 289-293. https://doi.org/10.1007/s10967-005-0906-3

34. Nagy, N.M., Jakab, M.A., Kónya, J., Antus, S. Appl. Clay Sci. 2002, 21, 213-216. https://doi.org/10.1016/S0169-1317(02)00066-2

35. Bradbury, M.H., Baeyens, B. Journal of Contaminant Hydrology 2003, 61, 329-338. https://doi.org/10.1016/S0169-7722(02)00125-0

36. Kozaki T., Liu, J., Sato, S. Physics and Chemistry of the Earth 2008, 33, 957-961. https://doi.org/10.1016/j.pce.2008.05.007

37. Kozaki, T,. Saito, N., Fujishima, A., Sato, S., Ohashi, H. Journal of Contaminant Hydrology 1998, 35, 67-75. https://doi.org/10.1016/S0169-7722(98)00116-8

38. Tournassat, C., Appelo, C.A.J. Geochimica et Cosmochimica Acta 2011, 75, 3698-3710. https://doi.org/10.1016/j.gca.2011.04.001

39. Nagy, N.M., Kónya, J. Radioanal. Nucl Chem 2013, 298, 1519-1526. https://doi.org/10.1007/s10967-013-2682-9

40. Kónya, J., Nagy, N. M., Földvári, M. J.Thermal Anal. Calorimetry 2005, 79, 537-543. https://doi.org/10.1007/s10973-005-0576-y

41. Theng, B.K.G. The chemistry of clay-organic reactions. London: Adam Hilger 1974

42. Theng, B.K.G. Clay-activated organic reactions. In International Clay Conference 1981. Developments in Sedimentology, eds. van Olphen, H., Veniale, F. 35:197-238. Amsterdam: Elsevier. 1992

43. Solomon, D.H., and D.G. Hawthorne. Chemistry of pigments and filter. New York: Wiley 1983.

44. Laszlo, P. Science 1986, 235,1473-1477. https://doi.org/10.1126/science.235.4795.1473

45. Laszlo, P. Accounts of Chemical Research 1986, 19, 121-127. https://doi.org/10.1021/ar00124a004

46. Adams, J.M., and R.W. McCabe. Clay minerals as catalysts. In Handbook of clay science $3^{\text {rd }}$ ed., eds. F. Bergaya, B.K.G. Theng, and G. Lagaly, 541-581. Amsterdam: Elsevier, 2008.

47. McCabe, R.W. Clay chemistry. In Inorganic Materials, $2^{\text {nd }}$ ed. , eds. D.W. Bruce, and D. O'Hare, 313-376. Chichester: Wiley 1996.

48. Bergaya, F., A. Aouad, and T. Mandalia. Pillared clays and clay minerals. In Handbook of clay science $3^{\text {rd }}$ ed., eds. F. Bergaya, B.K.G. Theng, and G. Lagaly, 393-421. Amsterdam: Elsevier 2008.

49. Kónya, J., Nagy, N.M. Soil and Tillage Research 2015, 150, 171-179. https://doi.org/10.1016/j.still.2015.01.002 


\section{Ion exchange processes in the "nano laboratory" of clay minerals}

A basic feature of layer silicates is the cation exchange. Layer silicates having isomorphic substitutions providing permanent negative layer charge have great cation exchange capacity. An important mineral is montmorillonite, its interlayer space can be considered as a "nano laboratory"; the cation exchange in this lab plays an important role both in nature and applications.

When studying ion exchange processes in clays the aspects have to be taken into consideration as follows:

- All the composition, layer charge, and cation exchange capacity changes site by site

- The cation exchange occurs in a closed space with high electrostatic strength

- High concentration of the hydrated cations in the interlayer space

- The layers are swelling by water uptake; the swelling is determined by the identity of the cations in the interlayer space

- the main mineral component, montmorillonite is plastic and forms tactoid structure

- adsorption is possible because of the high specific surface area

- the cations and other compounds in the interlayer space can react, and act as catalysts

- montmorillonite is strongly acidic.

During thermodynamic studies of the ion exchange, we have to take into account that the ion exchange is not adsorption because the adsorption takes place on the free sites of the sorbent, while ion exchange is the equivalent change of the ions already present on the sorbent. To do this, the law of mass action and the sorption isotherms are shown to be equivalent.

The identity of the cation in the interlayer influences the mechanical, swelling, and migration properties. In nature, sodium or calcium ions are present; the differences can be well seen in case of salty (sodium exchanged) and forest soils (calcium exchanged). These cations, however, can be exchanged another cations, such as micro nutrients of plants, polluting cations.
The role of cation exchange in the formation of pore system in bentonite rock is an important problem during the waste disposal. The interlayer cation influences mainly the migration of anion because of the differences in swelling and as a result the portion of interlayer water. The cesium cation sorption, however, is so strong that overcomes all other effects.

The interlayer cations and the other adsorbed species can take place in chemical reactions or can catalyze them. As an example of catalysis, the production of 1,1-diacetates is shown from aromatic aldehydes catalyzed by zinc-bentonite.

The chemical reactions (oxidation, hydrolysis, precipitation) of the interlayer cations can also be occurred. The oxidation of manganese(II)-bentonites to manganese(III,IV)-bentonites takes place in air at ambient temperature, the reaction is very slow, needs some years. Iron(III) ions can be encapsulated into the interlayer space from acetone solution. After the cation exchange, iron(III) ions hydrolyze with the interlayer water, producing an iron oxide, hydroxide nano layer.

When the interlayer cation can precipitate with an anion, the sorption of anion occurs in the interlayer space. For example, lanthanum exchanged bentonite is used for the sorption of phosphate ion, decreasing the eutrophication of groundwater.

The cation exchange can change the structure of the clay. The (001) basal spacing of montmorillonite depends on the ionic radius of rare earth cations. Moreover, the structure of crystal lattice can be changed, as published for the lanthanum cation exchange.

A special case of ion exchange is heterogeneous isotope exchange when only the mass numbers of the exchanging ions are different. This reaction is controlled by the increase of mixing entropy. This method was used to study the phosphate metabolism in soils; the ratio of weakly and tightly soluble phosphate, as well as the exchange rate under steady-state conditions can be determined. 